\title{
Building a Website as a Learning Media at SMP Negeri 1 Gunung Tanjung, Tasikmalaya Regency
}

\author{
Masiho Pandiangan \\ Program Studi Teknik Informatika, STMIK DCI Tasikmalaya, Indonesia
}

\section{Article Info}

\section{Article history:}

Received: $11 / 01 / 2021$

Revised: 06/02/2021

Accepted: $17 / 02 / 2020$

Available online 30/03/2021

\section{Keywords:}

Learning Media Junior High School, Websites.

\begin{abstract}
SMP Negeri 7 Tasikmalaya is a relatively young school, but the development of the number of students and the number of teachers as well as physically is quite rapid. Therefore, it is necessary to make a website so that people know the existence of SMP Negeri 7 Tasikmalaya. The era of the internet that is growing rapidly has given rise to a demand for mastery in making websites (websites). An attractive and interactive web site can be used as a way to improve personal or company image. Many programming languages can be used to build the web site. Among the many programming languages, there are standard languages that are always used, namely: Hyper Text Markup Language (HTML) for layout of web site pages.
\end{abstract}

This is an open access article under theCC BY-NClicense.

\section{Corresponding Author:}

Masiho Pandiangan,

Program Studi Teknik Informatika, STMIK DCI Tasikmalaya, Indonesia Email: masihoharahap@gmail.com

\section{Introduction}

Nowadays computers can be found in almost every government office, company, school or even household. The rapid development of computer technology, especially in the field of software, has made computers more user friendly and has made it a necessity for certain circles, for example in the world of education (Murphy, 2013) (Sahata Sitanggang, 2014). In carrying out the Teaching and Learning Process, both teachers and students really need information related to education (Mar'ah, Rusilowati, \& Sumarni, 2020) (Kartini, 2007).

The development of technology is getting faster day by day. Almost all fields of technology are now internet based. One of the technologies that we currently feel the benefits of is the word wide web or known as the web. The web is now the largest source of data because on the web a collection of documents are interconnected and can be accessed via an internet connection (Setiawan \& Nurkamid, 2012) (Nurkamid, 2009).

The need for a website in schools because it greatly facilitates the activities of the teaching and learning process for teachers, especially for subject teachers who are UN. make it easier for students to find information about materials, including predictions about the questions that will be taken to the UN (PADANGSIDIMPUAN \& HASIBUAN, n.d.) (Siahaan, 2008).

\section{Method}

The method used in compiling this thesis the author uses descriptive qualitative method. Qualitative research is research that cannot use mathematical, statistical or computer models (Nirmala, Isnarto, \& Mulyono, 2019) (Tandilling, 2012). The research process begins with developing 
basic assumptions and rules of thought that will be used in research. The assumptions and rules of thinking are then.

\subsection{Data collection technique}

In writing the final project required supporting data obtained by a relevant data collection method. Data collection methods used to obtain data are as follows.

a. Observation

Observation is a direct observation of an object to be studied in a short time and aims to get an overview of the object of research (Fitriani, 2017). Observations were made to observe directly the effect of information technology on students' understanding of learning about the subjects given.

b. Interview

Interviews are a way to collect data by conducting interviews or direct Q\&A with teaching staff at SMP Negeri 1 Gunungtanjung, Tasikmalaya Regency. A detailed list of questions that the author asked can be seen in the attachment.

c. Literature review

In this method, the authors quote from several reading sources related to the problems studied, which can be in the form of theories or opinions from several reading books. It is intended to provide a solid theoretical foundation through books or literature available in libraries and the internet.

\section{Results and Discussion}

\subsection{System Implementation}

a. Display Design

The web-based learning information system at SMP Negeri 1 Gunungtanjung, Tasikmalaya Regency has several menus which include an index page as the main page, information pages, pages containing material accompanied by animated images and practice questions. Following is the display for the main menu.

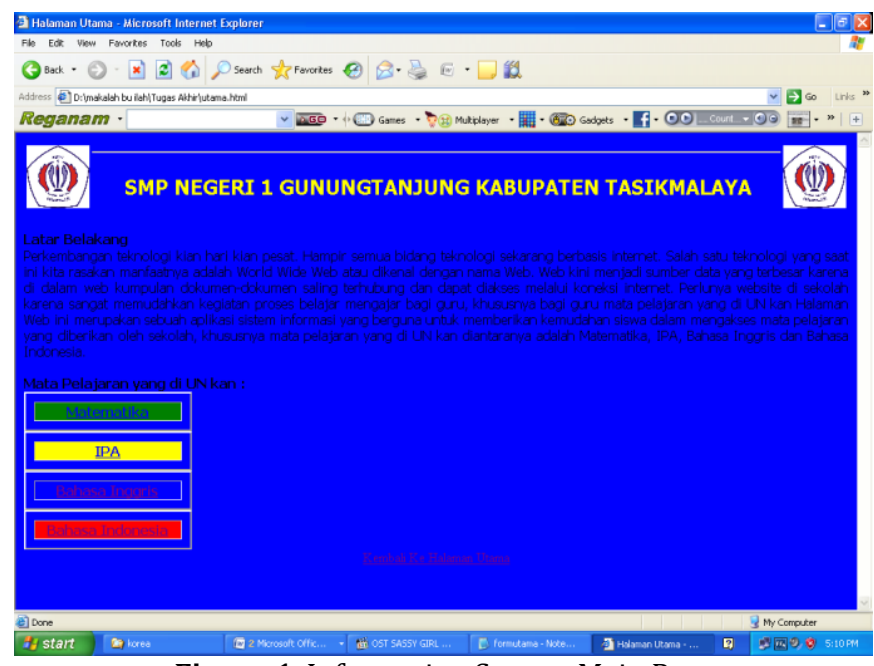

Figure 1. Information System Main Page

\section{b. Science Subject Page}

This page contains information regarding the discussion of science subjects including the definition of density, characteristics of substances, stress, capillarity and others. 


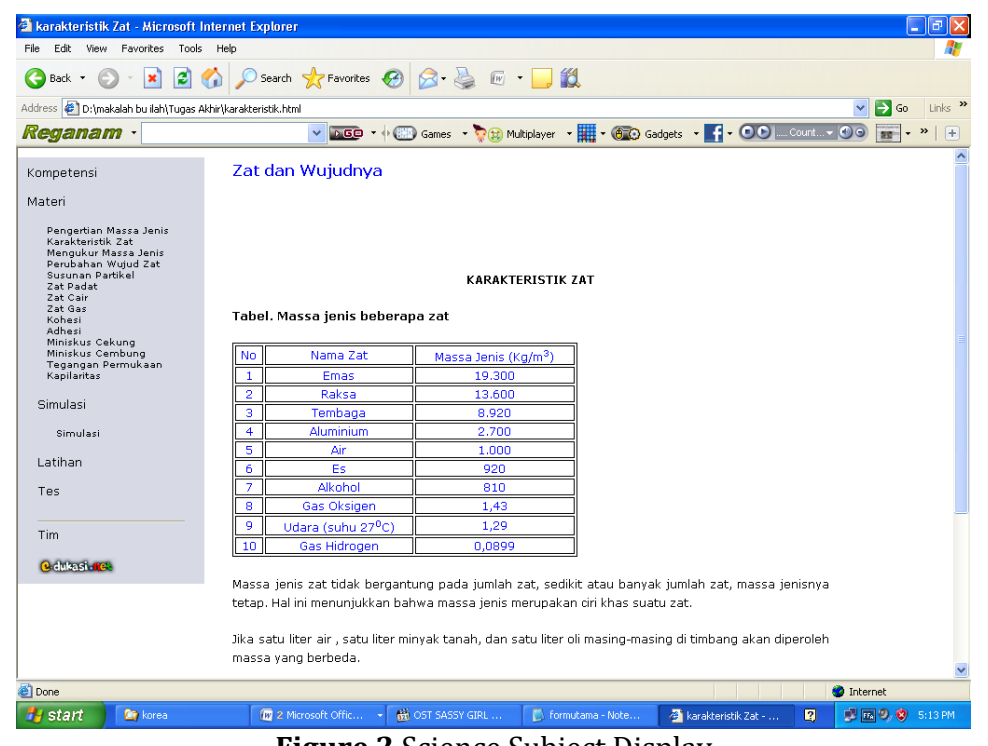

Figure 2.Science Subject Display

\section{c. Math Subjects Page}

This page contains information regarding the discussion of Mathematics subjects including the definition of density, characteristics of substances, tension, capillarity and others.

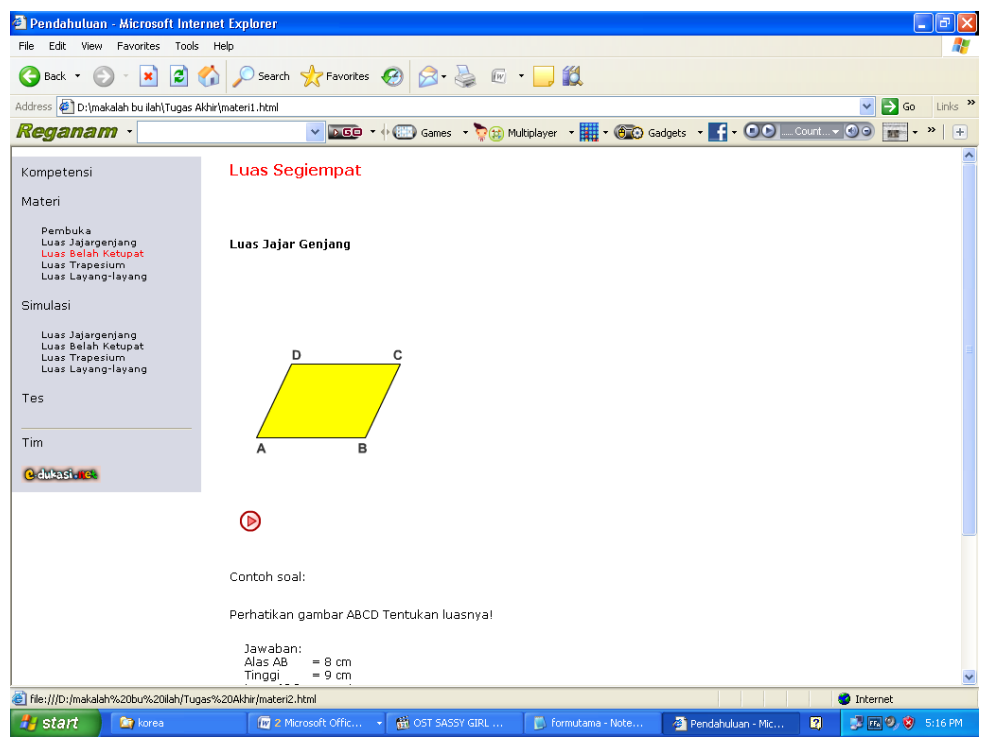

Figure 4.Math Subject Display

\section{Conclusion}

In designing a web-based learning information system at SMPN 1 Gunungtanjung, Tasikmalaya Regency, the author uses an HTML (Hypertext Markup Language) application with a notepad because this application is the easiest even though the appearance is still not optimal compared to Macromedia Dreamweaver 8.0. This information system provides a variety of information regarding any subjects at the National Examination, including Mathematics, Indonesian, Science, and English. In addition to displaying subject matter, this information system provides interactive practice questions so that students are more interested in learning. 


\section{Reference}

Fitriani, I. (2017). Evaluasi Kebijakan E-Ktp Dalam Mewujudkan Mutu Pelayanan Masyarakat Di Kelurahan Pela Mampang Kecamatan Mampang Prapatan Kota Administrasi Jakarta Selatan. Jurnal Renaissance, 2(01), 115124.

Kartini, T. (2007). Penggunaan metode role playing untuk meningkatkan minat siswa dalam pembelajaran pengetahuan sosial di kelas V SDN Cileunyi I Kecamatan Cileunyi Kabupaten Bandung. Jurnal Pendidikan Dasar, 8(1), 16-17.

Mar'ah, N. K., Rusilowati, A., \& Sumarni, W. (2020). Perubahan Proses Pembelajaran Daring Pada Siswa Sekolah Dasar di Tengah Pandemi Covid-19. Prosiding Seminar Nasional Pascasarjana (PROSNAMPAS), 3(1), 445452.

Murphy, B. I. (2013). Fasilitas Sistem Informasi Akademik Berbasis Web Untuk Sma Negeri Oleh Pt. Xl Axiata, Tbk Palembang.

Nirmala, M. D., Isnarto, I., \& Mulyono, M. (2019). Kemampuan Literasi dalam Menyelesaikan Soal Ujian Nasional Berbasis Komputer yang Mempunyai Daya Serap Rendah Siswa Kelas XII. Prosiding Seminar Nasional Pascasarjana (PROSNAMPAS), 2(1), 1126-1135.

Nurkamid, M. (2009). Aplikasi Bibliografi Perpustakaan Berbasis Teknologi Web Semantik. Sains Dan Teknol, 2(2).

PADANGSIDIMPUAN, K., \& HASIBUAN, S. (n.d.). MODEL PENGEMBANGAN KOMPETENSI PROFESIONAL GURU BERKELANJUTAN DENGAN MENGGUNAKAN TEKNOLOGI INFORMASI DAN KOMUNIKASI (STUDI PADA SEKOLAH MENENGAH ATAS (SMA) NEGERI.

Sahata Sitanggang, A. (2014). Penerapan Teknologi Smartphone Menggunakan Android Yang Berbasiskan Mobile Computing. JAMIKA-Jurnal Manajemen Informatika UNIKOM, 1(4).

Setiawan, R. R., \& Nurkamid, M. (2012). Teknologi Web Semantik Untuk Bibliografi Perpustakaan. Semantik, 2(1).

Siahaan, S. (2008). Mengapa Harus Menggunakan E-Learning Dalam Kegiatan Pembelajaran? Jurnal Teknodik, 4254.

Tandilling, E. (2012). Pengembangan instrumen untuk mengukur kemampuan komunikasi matematik, pemahaman matematik, dan selfregulated learning siswa dalam pembelajaran matematika di sekolah menengah atas. Jurnal Penelitian Pendidikan, 13(1), 24-31. 